\title{
C. Linnæus' Ideas Concerning Retribution and Fate
}

\author{
By K. ROB. V. WIKMAN
}

\section{SUMMARY'}

From the day in 1844 when the loose sheets from the hand of C. Linnæus which bear the title Nemesis divina, were found and entrusted to the care of Uppsala University Library, they have never ceased to arouse wonder and interest. The little volume, now bound, with its 203 octavo leaves, retains even today a good deal of its attraction as a reliquary for the most secret thoughts of the great scientist.

It is known that Linnæus wrote these leaves over a long period of time and kept them strictly secret. Dedicating the leaves to his son, Linnæus Junior, he wrote: "Some of these stories are perhaps told incorrectly; [if so] listen, say nothing, do not violate anybody's name and honour." This counsel has been followed piously until our days. There is no complete edition of the manuscript, only a selection, good in itself, published with a commentary by Elias and Thore Magnus Fries. Of this selection, which bears the title 'Carl von Linnés anteckningar öfver Nemesis Divina', the first edition was published in connection with the doctoral investiture at Uppsala in 1848 , and a second enlarged and revised edition in 1878 . This is still the only edition of scientific value and will therefore be used here.

Only in special cases do dates in Nemesis divina enable us to establish a chronological connection. But we may assume that Linnæus' ideas have changed somewhat in the course of time and that the differences between his youth and his maturity can be traced. Linnæus early evinces signs of old age.

\footnotetext{
I The paper will be published in full in a separate volume Lachesis and Nemesis.
} 
The exterior framework of Nemesis divina seems to derive from the 1760 's, when Linnæus was already an old man.

Linnæus' Nemesis divina has been interpreted in different ways. Crucial to me is its central problem: the ideas of fate and retribution, but these are, in turn, dependent on Linnæus' conception of God and nature and not least on his opinions concerning the unity and coherence of the natural and ethical order of the world.

From whatever sources Linnæus may have derived his religious ideas and whatever changes they may have undergone, his religious attitude in face of the works of nature remained unshaken. But Linnæus' religion, as we find it fragmentarily in these literary sources, was entirely undogmatic, untheological and, from a Christian point of view, even heterodox. Partly, this was in accord with his belief in the necessary immanent coherence in the processes of nature and the concomitant idea of the righteous divine order of the world. Crime and punishment appear to Linnæus to stand in a necessary connection, which is manifested in the divine decree of fate. This is in nuce his doctrine of nemesis which never postulates either punishment or recompense in a future life.

The concept of fate is deeply embedded in Linnæus' thinking. We find it already in the notes for Diaeta Naturalis, made in the r73o's. In Nemesis he says that fate is God's judgment, against which there is no appeal. Linnæus asks how free will (liberum arbitrium) should be harmonized with inescapable fate, and he illustrates it by saying that any man can hang himself, drown himself, cut his throat; he may freely choose not to do it. But if, for some reason, he is sentenced to death by the highest judge his death follows inevitably. Thus, man is free to commit a crime or to decline, but once it is committed, he cannot escape his punishment. Linnæus' argument is interesting because of the idea that divine retribution works $e x$ post facto, just as human retribution does. The problem of free will is seemingly abolished, but instead the contradiction becomes even more obvious, since this argument leads to pure occasionalism.

We need not travel far to find the principle of retribution taken to a logical extreme in Linnæus' time. How ruthlessly this was done in politics is shown by the bloody drama after the defeat in the war of $1741-1742$ and after the abortive attempt at a coup d'état in 1756 . These events are clearly reflected 
in Linnæus' Nemesis notes. Linnæus' idea of nemesis is obviously related to his cultural background. But this does not mean that it originated in popular beliefs. It would be more plausible to say that the Old Testament tradition, which Linnæus frequently refers to, has influenced his thinking. But most probably Linnæus' idea of nemesis has an independent origin. When he combines fate and retribution, this is the expression of an empirical determinism, which places crime and punishment in an inner relation to each other. There are allusions to the nemesis idea as early as the latter part of Diaeta naturalis. Man sins against God through ingratitude toward Him and through indifference (securitas) to the punishment that threatens him in this life. One injures one's neighbour through malice (malitiositate) and embezzlement (suppressione). The peasantry and tenants are impoverished so that "many become poor, which is not heeded, even if half the people starve to death".

Linnæus works inductively, trying to show the judgments of divine retribution. He collects cases, and he looks for a "system". This system is lex talionis. Linnæus' Nemesis divina is not a collection of exempla for biblical truths. The notes claim to be "empirical experience". Unfortunately Linnæus himself could not verify them.

We find that Linnæus in his thinking on retribution rarely applies the talio principle in a strict sense. Retribution works ex operato and in a new situation it operates according to the magical principles of similarity or contact. In various cases crime and punishment reflect each other in similar situations, but no real equilibrium is produced between them. The application of ius talionis has a predominantly numinous, only apparently a juridical character.

The crimes and vices that are censured by Linnæus include pride, arrogance, greed, ambition (ävlan), envy, malevolence, and ingratitude, which are illustrated by numerous quotations from the Bible and classical antiquity. In Nemesis also wealth and poverty, joy and friendship may be both good and evil. In the ethics of retribution the punishment of evil always preponderates over the remuneration of the good. Retributive indignation against the criminal is common to justice and religion. From the point of view of religion it is sin that punishes the sinner, and crime avenges itself. When crime is regarded as sin, the calamities of mankind are often understood as divine 
punishment. Crime and punishment are thus related through a sympathetic connection which according to the general principle of likeness and contact makes retribution stand out as a necessary force which is released in given situations. Retribution is understood as a revenging destiny which comes into effect according to religious-magical or juridical-moral principles, which can cooperate with or counteract each other in the historical process of evolution. Sin and crime are often identified as guilt and conceived as the material cause of punishment.

The nemesis of Linnæus is at the same time talio and numen, dike and tyche. There can reasonably be no real equivalence between these concepts. Retribution often becomes a juridical fiction, Nemesis only a fictitious Dike. The restrictive rules of talio merge into numinous fatalism. The sympathetic relationship between crime and punishment is regarded as a symbolizing likeness and this too on the final count becomes fictitious. Neither human nor divine justice can function without norms, and therefore the borderline between ius naturae and ius divinum must be highly arbitrary. In this way the nemesis of Linnæus will require not only social but also religious sanction. 